\title{
Severe Lactic Acidosis in a Patient with B-Cell Lymphoma: A Case Report and Review of the Literature
}

\author{
Farn Huei Chan, ${ }^{1}$ Daniel Carl, ${ }^{2}$ and Laurel J. Lyckholm ${ }^{1}$ \\ ${ }^{1}$ Department of Internal Medicine, Division of Hematology, Oncology and Palliative Care, Virginia Commonwealth University, \\ Richmond, VA 23298, USA \\ ${ }^{2}$ Department of Internal Medicine, Division of Nephrology, Virginia Commonwealth University, Richmond, VA 23298, USA
}

Correspondence should be addressed to Farn Huei Chan, fchan@mcvh-vcu.edu

Received 4 September 2009; Accepted 20 November 2009

Recommended by Estella M. Matutes

Lactic acidosis is commonly observed in clinical situations such as shock and sepsis, as a result of tissue hypoperfusion and hypoxia. Lymphoma and leukemia are among other clinical situations where lactic acidosis has been reported. We present a case of a 59year-old female with lactic acidosis who was found to have aggressive B-cell lymphoma. There have been 29 cases of lymphoma induced lactic acidosis reported thus far; however all reported cases have abnormal vital signs or concomitant medical conditions that may lead to lactic acidosis. The pathogenesis of malignancy-induced lactic acidosis is not well understood; however associated factors include increased glycolysis, increased lactate production by cancer cells, and decreased hepatic clearance of lactate. When it occurs, lactic acidosis is a poor prognostic sign in these patients. Prompt diagnosis and treatment of underlying lymphoma or leukemia remains the only way to achieve complete resolution of lactic acidosis in these patients.

Copyright (c) 2009 Farn Huei Chan et al. This is an open access article distributed under the Creative Commons Attribution License, which permits unrestricted use, distribution, and reproduction in any medium, provided the original work is properly cited.

\section{Introduction}

Lactic acidosis is a common cause of an anion gap acidosis that often carries a significant risk for mortality. Lactic acidosis most commonly results from an imbalance between oxygen delivery and oxygen demand (Type A). However, it can also occur in the absence of a recognizable impairment in systemic oxygen delivery, resulting from impaired oxidative phosphorylation (Type B). Type B lactic acidosis is associated with numerous conditions, including inborn errors of metabolism, drugs and toxins, systemic diseases (i.e., diabetes and sepsis), and less commonly, malignancy.

Lactic acidosis has been reported in cases of lymphoma and leukemia. The exact pathophysiology and the best way to manage lactic acidosis in this setting remain unclear. We present a case and review the literature relating to lactic acidosis in lymphoma.

\section{Case Report}

A previously healthy 59 -year-old high school teacher presented with severe fatigue, generalized weakness, decreased appetite, weight loss, and increased abdominal swelling for 2 months. She reported no fever, night sweats, cough, or urinary symptoms. On physical examination, she appeared cachectic with temporal muscle wasting. Blood pressure was $113 / 38$, heart rate was $134 / \mathrm{min}$, respiratory rate was $22 / \mathrm{min}$, temperature was $98.6^{\circ} \mathrm{F}$, and she was not hypoxic on room air. The spleen tip was palpated at $10 \mathrm{~cm}$ below the left costal margin. Physical exam findings were otherwise normal.

Laboratory data revealed sodium $134 \mathrm{mmol} / \mathrm{L}$, potassium $4.4 \mathrm{mmol} / \mathrm{L}$, chloride $93 \mathrm{mmol} / \mathrm{L}$, carbon dioxide $<10 \mathrm{mmol} / \mathrm{L}$, anion gap $>31$, blood urea nitrogen $(\mathrm{BUN})$ $25 \mathrm{mg} / \mathrm{dL}$, creatinine $0.6 \mathrm{mg} / \mathrm{dL}$, and glucose $87 \mathrm{mg} / \mathrm{dL}$. Other pertinent labs included leukocyte count $6.4 \times 10^{9} / \mathrm{L}$, hemoglobin $4.1 \mathrm{~g} / \mathrm{dL}$, platelet count $19 \times 10^{9} / \mathrm{L}$, aspartate transaminase (AST) $103 \mathrm{U} / \mathrm{L}$, alanine transaminase (ALT) $15 \mathrm{U} / \mathrm{L}$, alkaline phosphatase $104 \mathrm{U} / \mathrm{L}$, lactate dehydrogenase $(\mathrm{LDH}) 647 \mathrm{mmol} / \mathrm{L}$ (normal range $0.5-2.2 \mathrm{mmol} / \mathrm{L}$ ), haptoglobin $55 \mathrm{mg} / \mathrm{dL}$, uric acid $13.6 \mathrm{mg} / \mathrm{dL}$, and lactate $16.5 \mathrm{mmol} / \mathrm{L}$. Arterial blood gas revealed a $\mathrm{pH}$ of 7.33 , a $\mathrm{PCO}_{2}$ of $21 \mathrm{mmHg}$, and $\mathrm{PO}_{2}$ of $132 \mathrm{mmHg}$, with a bicarbonate of $11.2 \mathrm{mmol} / \mathrm{L}$. Peripheral blood smear revealed no blast cells or abnormal leukocytes. Blood cultures were negative. 


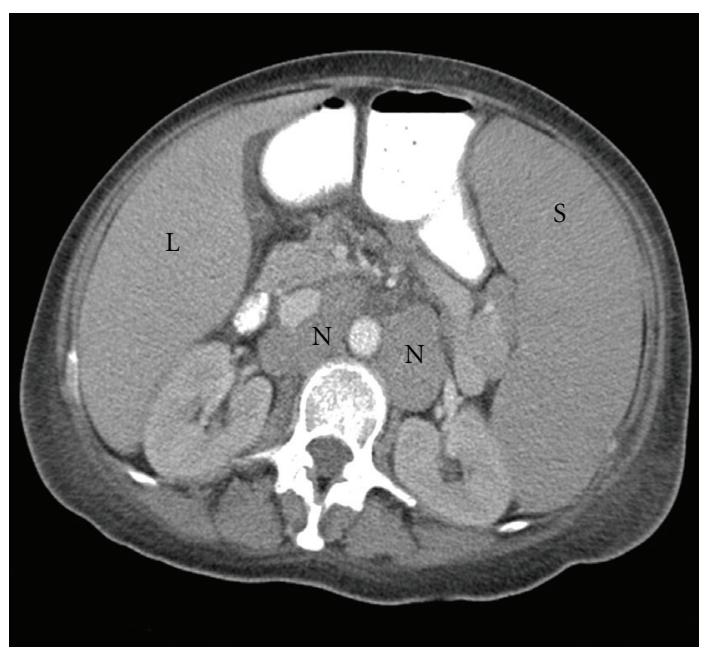

Figure 1: Computed tomography scan of the abdomen showed massive splenomegaly and extensive lymphadenopathy . (L: liver, S: spleen, N: lymphadenopathy).

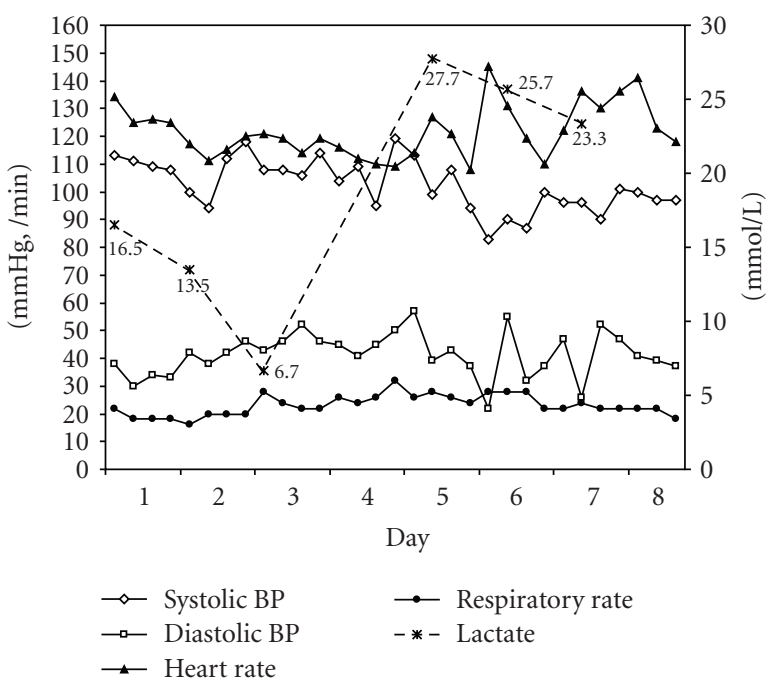

Figure 2: Correlation between lactate level and vital signs.

Computed tomography (CT) scan of the abdomen and pelvis revealed massive splenomegaly measuring $25 \mathrm{~cm}$ craniocaudally, and extensive lymphadenopathy in the abdomen and pelvis (Figure 1).

The patient was aggressively hydrated and received blood transfusions to improve her anemia. However, she remained tachycardic. Throughout her hospital course, her blood pressures remained stable. No source of infection or bleeding was identified. With these measures, lactate improved to $6.7 \mathrm{mmol} / \mathrm{L}$ but shortly after that rose to $27.7 \mathrm{mmol} / \mathrm{L}$ (Figures 2 and 3).

While awaiting pathological diagnosis, the patient deteriorated clinically, and on day 4, intravenous corticosteroids were administered for presumed high-grade lymphoma. In addition, a sodium bicarbonate infusion and allopurinol were initiated for tumor lysis syndrome prophylaxis.

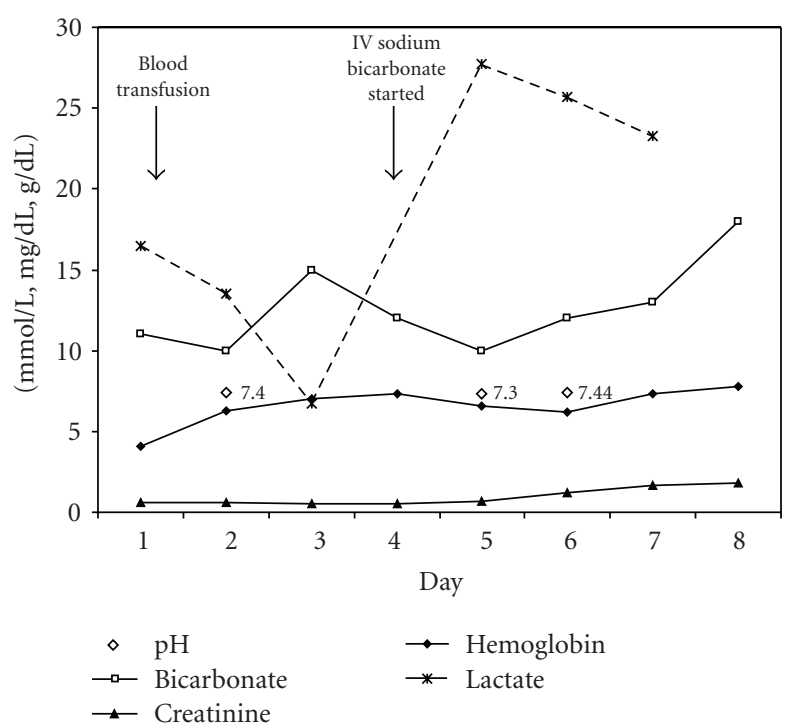

FIgure 3: Correlation between lactate level, $\mathrm{pH}$, bicarbonate, creatinine, and hemoglobin.

Bone marrow biopsy revealed a diffuse ( $>50 \%)$ infiltrate of cells positive for CD 45 and CD 20, negative for CD 5, CD 10, CD 23, and cyclin D1. GTG-banding studies reveal a very complex karyotype. However, morphologically the cells were not large enough to be called large B-cell lymphoma. The final diagnosis was CD 20-positive B-cell lymphoma. Cyclophosphamide, vincristine, and prednisone were started on day 7. On day 8 , she developed respiratory distress with new bilateral pulmonary infiltrates concerning for adult respiratory distress syndrome and became hypotensive requiring vasopressor support. Given the severity of the multiple organ failure, her family decided to withdraw support, and she died on hospital day 12. Autopsy revealed extensive lymphoma as well as diffuse pulmonary, kidney, and esophageal hemorrhage.

\section{Discussion}

Lactate is produced from the anaerobic metabolism of pyruvate, which in turn is generated from glucose via glycolysis. Therefore, lactate production is a surrogate marker of acidosis during a hypoxic state, and not the direct cause. Lactic acidosis is infrequently encountered in malignancies; yet when present portends an extremely poor prognosis [1]. Moreover, the strikingly high mortality associated with lactic acidosis has prompted some oncologists to consider this an oncological emergency [2]. Hematologic malignancies, including acute leukemias and high-grade lymphomas, are the most common neoplastic disorders associated with lactic acidosis. Twenty nine cases of lymphoma induced lactic acidosis have been published in English language journals (Table 1). Seven patients experienced either a partial or complete remission, three of whom subsequently expired from recurrence and there is no long-term followup on an additional two patients. As patients with malignancy induced lactic acidosis are often criticallyill, it is difficult to discern 
TABLE 1: Summary of all reported cases of lactic acidosis associated with lymphoma. (NR: normal range; BP: blood pressure; RR: respiratory rate; $\mathrm{P}$ : pulse; T: temperature.)

\begin{tabular}{|c|c|c|c|c|c|c|c|c|}
\hline Reference & Age & $\begin{array}{c}\text { Type of } \\
\text { lymphoma }\end{array}$ & $\begin{array}{c}\text { Lactate } \\
(\mathrm{mmol} / \mathrm{L})\end{array}$ & Vitals & $\begin{array}{c}\text { Directed treatment } \\
\text { of lactic acidosis }\end{array}$ & Chemo & Outcome & Comments \\
\hline $\begin{array}{l}\text { Friedenberg } \\
\text { et al. [3] }\end{array}$ & 75 & Follicular & 5.4 & BP NR P104 & None & Yes & $\begin{array}{l}\text { Died in } 2 \\
\text { days }\end{array}$ & \\
\hline $\begin{array}{l}\text { Friedenberg } \\
\text { et al. [3] }\end{array}$ & 54 & T-cell & 12 & ВР 120/50 Р 92 & None & Yes & $\begin{array}{l}\text { Died in } 10 \\
\text { weeks }\end{array}$ & \\
\hline $\begin{array}{l}\text { Friedenberg } \\
\text { et al. [3] }\end{array}$ & 54 & $\begin{array}{c}\text { Diffuse large } \\
\text { B-cell }\end{array}$ & 18 & ВР 96/40 P118 & Hemodialysis & Yes & $\begin{array}{l}\text { Died in } 4 \\
\text { days }\end{array}$ & $\begin{array}{l}\text { Concomitant } \\
\text { sepsis (presumed) }\end{array}$ \\
\hline He et al. [4] & 28 & $\begin{array}{c}\text { Natural } \\
\text { Killer/T-cell }\end{array}$ & 11.2 & NR & IV Bicarbonate & Yes & Remission & $\begin{array}{l}\text { Died from } \\
\text { recurrence after } \\
\text { undisclosed } \\
\text { period of time }\end{array}$ \\
\hline $\begin{array}{l}\text { Prikis et al. } \\
\text { [5] }\end{array}$ & 65 & Large B-cell & 18 & NR & $\begin{array}{c}\text { IV bicarbonate and } \\
\text { dialysis }\end{array}$ & Yes & Remission & $\begin{array}{l}\text { Sustained low } \\
\text { efficiency dialysis }\end{array}$ \\
\hline $\begin{array}{l}\text { Dogan et al. } \\
{[6]}\end{array}$ & 24 & Large B-cell & 33.0 & $\begin{array}{l}\text { BP 100/60 P } 95 \\
\text { RR18 T } 36.7 \text { C }\end{array}$ & $\begin{array}{l}\text { IV Bicarbonate and } \\
\text { Hemodialysis }\end{array}$ & Yes & $\begin{array}{l}\text { Died within } \\
10 \text { days }\end{array}$ & \\
\hline $\begin{array}{l}\text { Glasheen and } \\
\text { Sorensen [7] }\end{array}$ & 74 & Burkitt's & 15.8 & NR & None & No & $\begin{array}{c}\text { Died in } 13 \\
\text { days }\end{array}$ & \\
\hline $\begin{array}{l}\text { Ohtsubo } \\
\text { et al. [8] }\end{array}$ & 77 & Mantle Cell & 26.3 & NR & IV Bicarbonate & Yes & Remission & \\
\hline $\begin{array}{l}\text { DiComite } \\
\text { et al. [9] }\end{array}$ & 64 & Large B-cell & 9.0 & NR & IV Bicarbonate & Yes & Died & $\begin{array}{l}\text { Unclear time to } \\
\text { death }\end{array}$ \\
\hline $\begin{array}{l}\text { Sillos et al. } \\
{[1]}\end{array}$ & 18 & Large T-cell & 15.4 & NR & IV bicarbonate & Yes & Remission & $\begin{array}{l}\text { Lymphoma } \\
\text { recurred and died } \\
\text { in } 7 \text { months }\end{array}$ \\
\hline $\begin{array}{l}\text { Thakur et al. } \\
{[10]}\end{array}$ & 82 & Hodgkin's & 11.5 & NR & IV bicarbonate & No & $\begin{array}{c}\text { Died in } 3 \\
\text { days }\end{array}$ & \\
\hline $\begin{array}{l}\text { Yasin and } \\
\text { Hartranft } \\
{[11]}\end{array}$ & 76 & Large B-cell & 13.1 & NR & None & No & $\begin{array}{l}\text { Died in } 7 \\
\text { days }\end{array}$ & $\begin{array}{l}\text { Presumed } \\
\text { ascending } \\
\text { cholangitis. Had } \\
\text { two exploratory } \\
\text { operations }\end{array}$ \\
\hline $\begin{array}{l}\text { Durig et al. } \\
{[12]}\end{array}$ & 71 & $\begin{array}{l}\text { Non- } \\
\text { Hodgkin's }\end{array}$ & 17.4 & BP 120/60 P120 & IV Bicarbonate & Yes & $\begin{array}{l}\text { Died in } 14 \\
\text { days }\end{array}$ & \\
\hline $\begin{array}{l}\text { Scheuleer- } \\
\text { Holmes et al. } \\
{[13]}\end{array}$ & 54 & $\begin{array}{l}\text { Non- } \\
\text { Hodgkin's }\end{array}$ & 16.4 & $\begin{array}{l}\text { BP 160/90 P } 92 \\
\text { RR 26 T } 37.1 \text { C }\end{array}$ & IV Bicarbonate & Yes & $\begin{array}{l}\text { Died within } 3 \\
\text { months }\end{array}$ & \\
\hline $\begin{array}{l}\text { Caspar and } \\
\text { Oelz [14] }\end{array}$ & 74 & $\begin{array}{l}\text { Non- } \\
\text { Hodgkin's }\end{array}$ & 14.8 & NR & None & No & $\begin{array}{l}\text { Died in } 2 \\
\text { days }\end{array}$ & \\
\hline $\begin{array}{l}\text { Caspar and } \\
\text { Oelz [14] }\end{array}$ & 71 & $\begin{array}{c}\text { Non- } \\
\text { Hodgkin's }\end{array}$ & 12.2 & $\begin{array}{c}\text { BP } 165 / 100 \mathrm{P} \\
100\end{array}$ & IV Bicarbonate & Yes & Remission & Died in 6 months \\
\hline $\begin{array}{l}\text { Caspar and } \\
\text { Oelz [14] }\end{array}$ & 34 & $\begin{array}{l}\text { Non- } \\
\text { Hodgkin's }\end{array}$ & 23.6 & NR & IV Bicarbonate & Yes & Remission & $\begin{array}{l}\text { Lactic acidosis } \\
\text { occurred after } \\
\text { exploratory } \\
\text { operation }\end{array}$ \\
\hline $\begin{array}{l}\text { Doolittle } \\
\text { et al. [15] }\end{array}$ & 19 & $\begin{array}{c}\text { Diffuse } \\
\text { Histiocytic }\end{array}$ & 21.8 & $\begin{array}{c}\text { BP 90/60 P } 120 \\
\text { RR 24, Temp } \\
101 \mathrm{~F}\end{array}$ & IV Bicarbonate & Yes & $\begin{array}{l}\text { Died in } 5 \\
\text { weeks }\end{array}$ & $\begin{array}{l}\text { Blood cultures } \\
\text { negative }\end{array}$ \\
\hline $\begin{array}{l}\text { Doolittle } \\
\text { et al. [15] }\end{array}$ & 60 & Hodgkin's & 16.3 & NR & IV Bicarbonate & Yes & $\begin{array}{l}\text { Died in } 24 \\
\text { days }\end{array}$ & \\
\hline $\begin{array}{l}\text { Vandermolen } \\
\text { et al. [16] }\end{array}$ & 32 & $\begin{array}{l}\text { Non- } \\
\text { Hodgkin's }\end{array}$ & 32 & NR & None & Yes & Remission & \\
\hline
\end{tabular}


Table 1: Continued.

\begin{tabular}{|c|c|c|c|c|c|c|c|c|}
\hline Reference & Age & $\begin{array}{c}\text { Type of } \\
\text { lymphoma }\end{array}$ & $\begin{array}{c}\text { Lactate } \\
(\mathrm{mmol} / \mathrm{L})\end{array}$ & Vitals & $\begin{array}{c}\text { Directed treatment } \\
\text { of lactic acidosis }\end{array}$ & Chemo & Outcome & Comments \\
\hline $\begin{array}{l}\text { Johnson and } \\
\text { Whelan [17] }\end{array}$ & 21 & Non-Hodgkin's & 16.1 & NR & IV Bicarbonate & Yes & $\begin{array}{c}\text { Died in } 14 \\
\text { days }\end{array}$ & $\begin{array}{l}\text { WBC } 27,700 \text { and } \\
\text { presumed sepsis }\end{array}$ \\
\hline $\begin{array}{l}\text { Leyden et al. } \\
{[18]}\end{array}$ & 47 & Hodgkin's & 20.0 & NR & IV Bicarbonate & Yes & $\begin{array}{c}\text { Died within } 6 \\
\text { days }\end{array}$ & Pneumonia \\
\hline $\begin{array}{l}\text { Leyden et al. } \\
{[18]}\end{array}$ & 61 & Non-Hodgkin's & 46.8 & NR & IV Bicarbonate & Yes & $\begin{array}{l}\text { Died in one } \\
\text { day }\end{array}$ & $\begin{array}{l}\text { Gastrointestinal } \\
\text { hemorrhage with } \\
\text { hemoglobin of } \\
4.0 \mathrm{~g} / \mathrm{dL}\end{array}$ \\
\hline $\begin{array}{l}\text { Nadiminti } \\
\text { et al. [19] }\end{array}$ & 30 & Hodgkin's & 14 & BР 120/80 P106 & IV bicarbonate & Yes & $\begin{array}{l}\text { Died in } 4 \\
\text { weeks }\end{array}$ & \\
\hline $\begin{array}{l}\text { Mintz et al. } \\
{[20]}\end{array}$ & 65 & Histiocytic & 21.8 & $\begin{array}{c}\text { BP } 114 / 66 \text { P } 124 \\
\text { RR } 32\end{array}$ & IV Bicarbonate & No & $\begin{array}{l}\text { Died in } 4 \\
\text { days }\end{array}$ & \\
\hline $\begin{array}{l}\text { Mintz et al. } \\
{[20]}\end{array}$ & 34 & Histiocytic & 14.2 & $\begin{array}{c}\text { BP 120/75 P100 } \\
\text { T 39C }\end{array}$ & IV Bicarbonate & Yes & $\begin{array}{l}\text { Died in } 8 \\
\text { days }\end{array}$ & \\
\hline $\begin{array}{l}\text { Mintz et al. } \\
{[20]}\end{array}$ & 60 & Histiocytic & 5.9 & $\begin{array}{c}\text { BP } 100 / 65 \text { P } 124 \\
\text { RR } 30\end{array}$ & None & Yes & $\begin{array}{l}\text { Died in } 3 \\
\text { weeks }\end{array}$ & \\
\hline $\begin{array}{l}\text { Mintz et al. } \\
{[20]}\end{array}$ & 58 & Histiocytic & 4.5 & $\begin{array}{l}\text { BP 90/60 P } 112 \\
\text { RR 50 T 39C }\end{array}$ & None & Yes & $\begin{array}{l}\text { Died in } 2 \\
\text { weeks }\end{array}$ & \\
\hline $\begin{array}{l}\text { Scheerer et al. } \\
{[21]}\end{array}$ & 47 & Hodgkin's & 8.8 & BP 112/80 P110 & IV bicarbonate & Yes & $\begin{array}{l}\text { Died in } 11 \\
\text { days }\end{array}$ & \\
\hline
\end{tabular}

whether the etiology of lactic acidosis is completely a result from the malignancy and not from other potential causes of Type A lactic acidosis (i.e., sepsis, hypotension, hypoxia, etc.). In the patient we present above, she did not have hypoxia or significant hypotension when the lactic acidosis was discovered. The lactic acidosis persisted despite volume repletion, including blood transfusions. Furthermore, we could not identify a source of infection and her lactic acidosis preceded her intensive care visit. However, she was anemic, tachycardic, and tachypneic at presentation. Therefore, it is impossible to conclude there were no additional influences that may have led to Type A lactic acidosis. Upon reviewing the current literature of lymphoma induced lactic acidosis, many cases did have concomitant sepsis, anemia, surgical procedures, or abnormal vital signs (Table 1). Accordingly, every published case that reported vital signs had at least one vital sign indicative of systemic inflammatory response. As the majority of cases to date had concomitant factors that potentially could lead to lactic acidosis, as in the case we present above, the true incidence of lymphoma induced lactic acidosis remains cloudy.

The pathogenesis of lactic acidosis in lymphoma is incompletely understood and likely multifactorial. Liver metastasis and dysfunction is often cited as a potential cause because of reduced hepatic utilization of lactate via gluconeogenesis [7]. However, lactic acidosis can occur in the absence of liver dysfunction [1, 22, 23]. In fact, Sillos et al. reported $19 \%$ of patients with lactic acidosis in the setting of hematological malignancies did not have liver involvement [1]. Furthermore, lactic acidosis is uncommon in patients with cirrhosis or fulminant hepatic failure in the absence of malignancy [24]. Accordingly, although liver dysfunction may contribute to the development of lactic acidosis, it is unlikely to be the sole cause. Another potential mechanism for lactic acidosis is increased glycolytic activity, with a subsequent increase in lactate acid generation, in cancer cells. Further supporting this hypothesis, several cases have been characterized by recurrent hypoglycemia, presumably related to increased glycolysis [7, 9, 12]. Overexpression of type II hexokinase [25], a glycolytic enzyme found in mitochondria, or increased IGF-binding protein (IGFBP) activity, has been implicated in the increased glycolysis in cancer cells [1]. Finally, excessive lactate production may result from highly aggressive tumors that simply outgrow their blood supply [26]. In essence, there is production of lactate from local hypoxia in the absence of any systemic hypoxia or hypoperfusion.

Regardless of etiology, the treatment for lactic acidosis is to discern and correct the underlying mechanism producing the lactate, as well as to ensure adequate oxygen delivery in cases of hypoxia. Accordingly, in malignancy derived lactic acidosis, chemotherapy is the primary treatment modality. As demonstrated in Table 1, the only treatment modality that consistently leads to remission was initiation of chemotherapy. Of the 29 reported cases of lymphoma induced lactic acidosis, only seven went into remission, all of whom received chemotherapy. Of the seven cases who went into remission, the lactate levels normalized in 6 (one case did not report what happened to the lactate levels after chemotherapy). In five of the six cases, resolution of the lactic acidosis occurred as early as 15 hours and up to 3 days after starting chemotherapy. In the remaining case, the lactate level normalized weeks after chemotherapy was introduced; however, did so within 2 days of starting salvage chemotherapy. Thus, it is probably safe to conclude that if lactic acidosis improves after chemotherapy, it occurs in 
timely manner. Additionally, it is conceivable that prompt resolution of lactic acidosis could be a surrogate marker of inducing remission.

Both intravenous (IV) bicarbonate and hemodialysis have been used to control the lactic acidosis until chemotherapy can treat the malignancy. The use of IV bicarbonate as an interim treatment of profound acidosis (in either the presence or absence of malignancy) remains a contentious issue [27-30]. As severe acidosis can cause respiratory fatigue and hemodynamic instability, intravenous bicarbonate is often used to attenuate the sequelae of systemic acidosis. However, there are potential side effects from using IV sodium bicarbonate. The most obvious of which are hypervolemia and hypernatremia [31]. Additionally, sodium bicarbonate infusion may actually increase lactic acid production [28]. The rise in lactate levels has been seen in human $[32]$ and animal $[33,34]$ studies. The decreased oxygen delivery has been postulated to occur from both a reduction in $\mathrm{PaO}_{2}$ [35] as well as increased affinity of oxygen to hemoglobin resulting from the rise in systemic $\mathrm{pH}$ following IV bicarbonate infusion [36]. The effect of IV bicarbonate on mortality or lactate concentrations in the setting of malignancy induced lactic acidosis has not been directly studied. From our review of the literature, 20 of the 29 cases used IV bicarbonate to treat the acidosis. Two patients received IV bicarbonate without adjunctive chemotherapy, and both died within days. Of the 7 patients who went into remission, 6 were on IV bicarbonate. Although it is unlikely that bicarbonate administration provides any mortality benefit beyond chemotherapy, this has not been directly studied.

Renal replacement therapy (RRT), including hemodialysis, peritoneal dialysis, or hemofiltration can be used to remove lactate and correct acidosis [37]. Prikis et al. recently reported a case of lymphoma induced lactic acidosis successfully treated with sustained low efficiency dialysis implemented as a temporary measure to correct acidosis and hypervolemia until chemotherapy was initiated [5]. Two other cases of lymphoma induced lactic acidosis have been treated with hemodialysis and chemotherapy, both of whom died within 10 days. As the prognosis of lymphoma induced lactic acidosis is grim, the only hope for remission is starting chemotherapy. Although IV bicarbonate and hemodialysis can be implemented in an attempt to control the acidosis, it must be emphasized that these measures should be viewed as a bridge until the underlying cause is treated.

In conclusion, lactic acidosis is an ominous sign in patients with lymphoma or leukemia. The exact pathogenesis of this condition remains unclear. Prompt diagnosis and early treatment of underlying lymphoma or leukemia is the only way to achieve complete resolution of lactic acidosis in these patients.

\section{References}

[1] E. M. Sillos, J. L. Shenep, G. A. Burghen, C.-H. Pui, F. G. Behm, and J. T. Sandlund, "Lactic acidosis: a metabolic complication of hematologic malignancies: case report and review of the literature," Cancer, vol. 92, no. 9, pp. 2237-2246, 2001.
[2] F. I. Jabr, "Lactic acidosis in patients with neoplasms: an oncologic emergency," Mayo Clinic Proceedings, vol. 81, no. 11, pp. 1505-1506, 2006.

[3] A. S. Friedenberg, D. E. Brandoff, and F. J. Schiffman, "Type B lactic acidosis as a severe metabolic complication in lymphoma and leukemia: a case series from a single institution and literature review," Medicine, vol. 86, no. 4, pp. 225-232, 2007.

[4] Y.-F. He, W. Wei, Z.-M. Sun, et al., "Fatal lactic acidosis and hypoglycemia in a patient with relapsed natural killer/T-cell lymphoma," Advances in Therapy, vol. 24, no. 3, pp. 505-509, 2007.

[5] M. Prikis, V. Bhasin, M. P. Young, F. J. Gennari, and J. M. Rimmer, "Sustained low-efficiency dialysis as a treatment modality in a patient with lymphoma-associated lactic acidosis," Nephrology Dialysis Transplantation, vol. 22, no. 8, pp. 2383-2385, 2007.

[6] E. Dogan, R. Erkoc, H. Sayarlioglu, S. Alici, I. Dilek, and O. Alici, "Fatal lactic acidosis due to leukemic transformation in a patient with non-Hodgkin's lymphoma: case report," Advances in Therapy, vol. 22, no. 5, pp. 443-446, 2005.

[7] J. J. Glasheen and M. D. Sorensen, "Burkitt's lymphoma presenting with lactic acidosis and hypoglycemia-a case presentation," Leukemia and Lymphoma, vol. 46, no. 2, pp. 281-283, 2005.

[8] K. Ohtsubo, R. Imamura, R. Seki, et al., "Blastoid variant of mantle cell lymphoma with lactic acidosis: a case report," International Journal of Hematology, vol. 80, no. 5, pp. 428431, 2004.

[9] G. Di Comite, L. Dagna, P. M. Piatti, L. D. Monti, F. Tantardini, and L. Praderio, "Hypoglycaemia and lactic acidosis in a MALT non Hodgkin's lymphoma," Leukemia and Lymphoma, vol. 43, no. 6, pp. 1341-1342, 2002.

[10] V. Thakur, G. Sander, and S. T. Rab, “Hodgkin's disease and lactic acidosis," Nephron, vol. 88, no. 3, pp. 276-277, 2001.

[11] M. Yasin and T. H. Hartranft, "Primary hepatic lymphoma: unusual presentation and clinical course," American Surgeon, vol. 63, no. 11, pp. 951-953, 1997.

[12] J. Dürig, W. Fiedler, M. De Wit, M. Steffen, and D. K. Hossfeld, "Lactic acidosis and hypoglycemia in a patient with highgrade non-Hodgkin's lymphoma and elevated circulating TNF- $\alpha$," Annals of Hematology, vol. 72, no. 2, pp. 97-99, 1996.

[13] M. L. Scheurleer-Hommes, M. R. Schaafsma, and J. C. KluinNelemans, "Lactic acidosis in a patient with B-cell nonHodgkin's lymphoma," Leukemia, vol. 8, no. 6, pp. 1065-1066, 1994.

[14] C. B. Caspar and O. Oelz, "Lactic acidosis in malignant lymphoma," American Journal of Medicine, vol. 91, no. 2, pp. 197-198, 1991.

[15] G. C. Doolittle, M. W. Wurster, C. S. Rosenfeld, and D. C. Bodensteiner, "Malignancy-induced lactic acidosis," Southern Medical Journal, vol. 81, no. 4, pp. 533-536, 1988.

[16] L. A. VanderMolen, S. Swain, and D. L. Longo, "Lactic acidosis in lymphoma: prompt resolution with therapy directed at lymphoma," Journal of the National Cancer Institute, vol. 80, no. 13, pp. 1077-1078, 1988.

[17] D. A. Johnson and T. V. Whelan, "Lactic acidosis—a review of the association with neoplastic disorder," Military Medicine, vol. 150, no. 4, pp. 206-208, 1985.

[18] M. Leyden, J. Sullivan, J. Szer, and G. Brodie, "Fatal lactic acidosis in lymphoma. A report of two cases," Australian and New Zealand Journal of Medicine, vol. 13, no. 2, pp. 179-180, 1983. 
[19] Y. Nadiminti, J. C. Wang, and S.-Y. Chou, "Lactic acidosis associated with Hodgkin's disease. Response to chemotherapy," The New England Journal of Medicine, vol. 303, no. 1, pp. 15$17,1980$.

[20] U. Mintz, D. L. Sweet Jr., J. D. Bitran, and J. E. Ultmann, "Lactic acidosis and diffuse histiocytic lymphoma (DHL)," American Journal of Hematology, vol. 4, no. 4, pp. 359-365, 1978.

[21] P. P. Scheerer, R. V. Pierre, D. L. Schwartz, et al., "ReedSternberg-Cell leukemia and lactic acidosis; unusual manifestations of Hodgkin's disease," The New England Journal of Medicine, vol. 270, pp. 274-278, 1964.

[22] K. S. Rao, R. Mehta, and J. Ferlinz, "Unusual presentation of cancer-induced lactic acidosis," Postgraduate Medical Journal, vol. 64 , no. 752 , p. $475,1988$.

[23] M. Fujimura, H. Shirasaki, K. Kasahara, and T. Matsuda, "Small cell lung cancer accompanied by lactic acidosis and syndrome of inappropriate secretion of antidiuretic hormone," Lung Cancer, vol. 22, no. 3, pp. 251-254, 1998.

[24] C. O. Record, R. A. Iles, R. D. Cohen, and R. Williams, "Acid base and metabolic disturbances in fulminant hepatic failure," Gut, vol. 16, no. 2, pp. 144-149, 1975.

[25] S. Mazurek, C. B. Boschek, and E. Eigenbrodt, "The role of phosphometabolites in cell proliferation, energy metabolism, and tumor therapy," Journal of Bioenergetics and Biomembranes, vol. 29, no. 4, pp. 315-330, 1997.

[26] S. Archer and B. Bache-Wiig, "Lactic acidosis B associated with solid tumors," Minnesota Medicine, vol. 69, no. 9, pp. 511-514, 1986.

[27] D. Mathieu, R. Neviere, V. Billard, M. Fleyfel, and F. Wattel, "Effects of bicarbonate therapy on hemodynamics and tissue oxygenation in patients with lactic acidosis: a prospective, controlled clinical study," Critical Care Medicine, vol. 19, no. 11, pp. 1352-1356, 1991.

[28] S. M. Forsythe and G. A. Schmidt, "Sodium bicarbonate for the treatment of lactic acidosis," Chest, vol. 117, no. 1, pp. 260 267, 2000.

[29] B. Cuhaci, J. Lee, Z. Ahmed, S. M. Forsythe, and G. A. Schmidt, "Sodium bicarbonate controversy in lactic acidosis," Chest, vol. 118, no. 3, pp. 882-884, 2000.

[30] M. L. Halperin, S. Cheema-Dhadli, F. A. Halperin, and K. S. Kamel, "Rationale for the use of sodium bicarbonate in a patient with lactic acidosis due to a poor cardiac output," Nephron, vol. 66, no. 3, pp. 258-261, 1994.

[31] J. A. Mattar, M. H. Weil, H. Shubin, and L. Stein, "Cardiac arrest in the critically ill—part II: hyperosmolal states following cardiac arrest," American Journal of Medicine, vol. 56, no. 2, pp. 162-168, 1974.

[32] A. L. A. Fields, S. L. Wolman, and M. L. Halperin, "Chronic lactic acidosis in a patient with cancer: therapy and metabolic consequences," Cancer, vol. 47, no. 8, pp. 2026-2029, 1981.

[33] H. Graf, W. Leach, and A. I. Arieff, "Metabolic effects of sodium bicarbonate in hypoxic lactic acidosis in dogs," The American Journal of Physiology, vol. 249, no. 5, part 2, pp. F630-635, 1985.

[34] K. H. Rhee, L. O. Toro, G. G. McDonald, R. L. Nunnally, and D. L. Levin, "Carbicarb, sodium bicarbonate, and sodium chloride in hypoxic lactic acidosis: effect on arterial blood gases, lactate concentrations, hemodynamic variables, and myocardial intracellular pH," Chest, vol. 104, no. 3, pp. 913918, 1993.

[35] R. M. Bersin, K. Chatterjee, and A. I. Arieff, "Metabolic and hemodynamic consequences of sodium bicarbonate administration in patients with heart disease," American Journal of Medicine, vol. 87, no. 1, pp. 7-14, 1989.
[36] A. J. Bellingham, J. C. Detter, and C. Lenfant, "Regulatory mechanisms of hemoglobin oxygen affinity in acidosis and alkalosis," Journal of Clinical Investigation, vol. 50, no. 3, pp. 700-706, 1971.

[37] P. J. Fall and H. M. Szerlip, "Lactic acidosis: from sour milk to septic shock," Journal of Intensive Care Medicine, vol. 20, no. 5, pp. 255-271, 2005. 


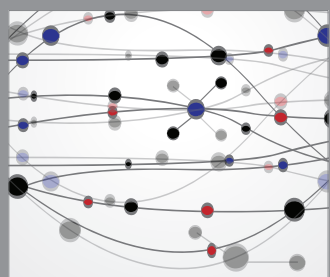

The Scientific World Journal
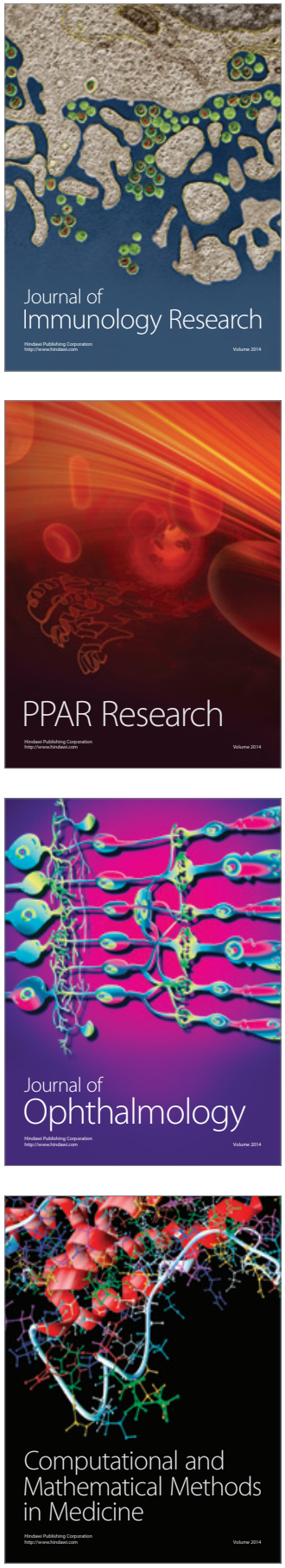

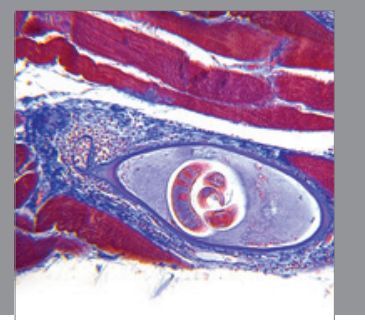

Gastroenterology

Research and Practice
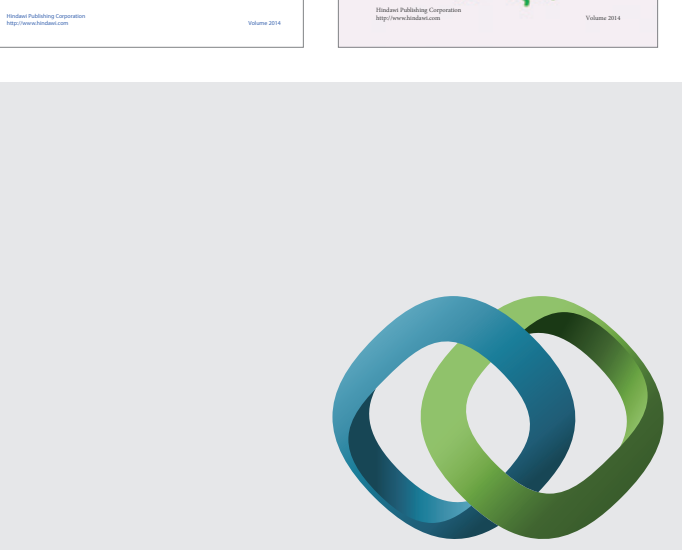

\section{Hindawi}

Submit your manuscripts at

http://www.hindawi.com
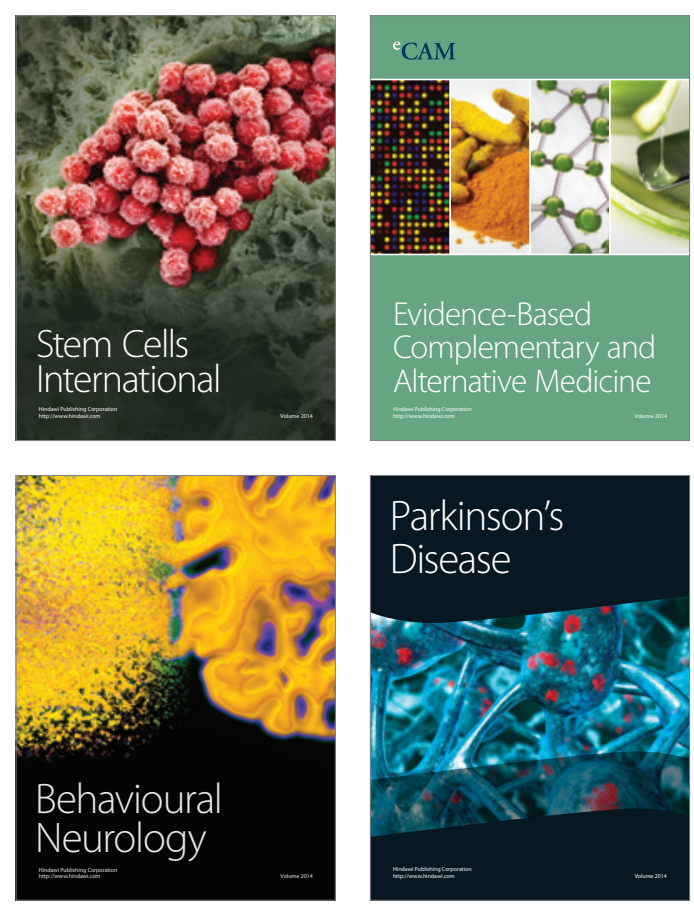

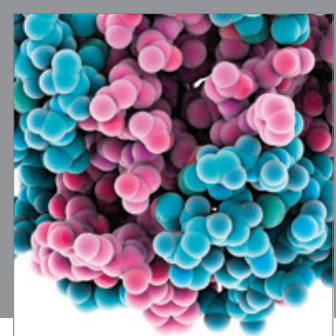

Journal of
Diabetes Research

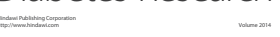

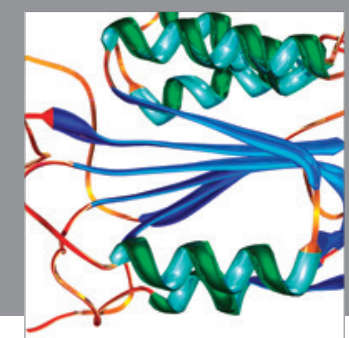

Disease Markers
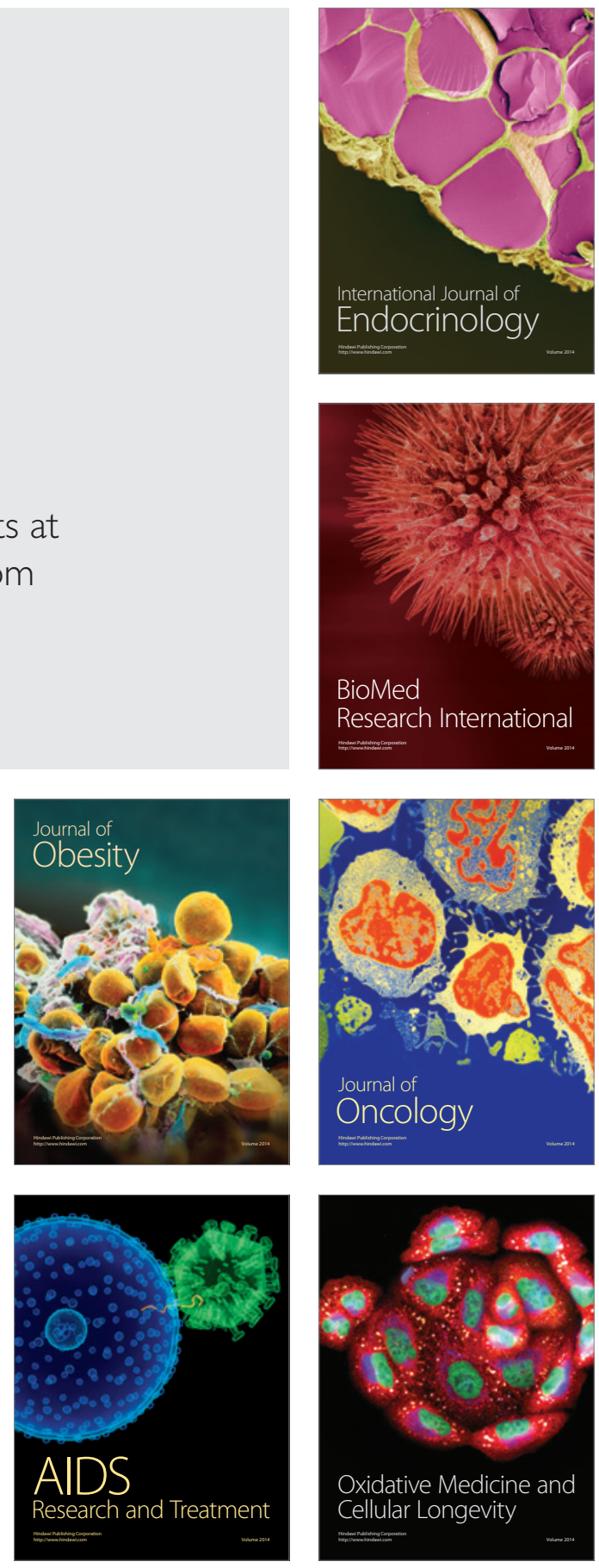